\title{
ГЕОЛОГИЧЕСКОЕ РАЗВИТИЕ И НЕФТЕГАЗОНОСНОСТЬ ЛОКАЛЬНЫХ ПОДНЯТИЙ БАКИНСКОГО АРХИПЕЛАГА ЮЖНО-КАСПИЙСКОГО БАССЕЙНА
}

Нариманов Нариман Рустам оглы', nariman.narimanov40@asoiu.edu.az

Мухтарова Хураман Зиядхан гызы', mukhtarova.khuraman@mail.ru

\author{
Насибова Гюльтер Джумшуд гызы', \\ gultar_nasibova_1@yahoo.com \\ ' Азербайджанский Государственный Университет Нефти и Промышленности, \\ Азербайджан, AZE1010, г. Баку, пр. Азадлыг, 20.
}

Актуальность исследования обусловлена необходимостью расширения ресурсной базы углеводородов западного борта Южно-Каспийского бассейна и увеличения добычи на некоторых нефтегазовых месторождениях Бакинского Архипелага. Эти исследования могут предоставить более достоверную информацию по изучаемым структурам, а полученные результаты могут способствовать дальнейшему открытию новых структур с углеводородным потенциалом именно в этой зоне Южно-Каспийского бассейна.

Цель: определение характера развития структур Аран-дениз, Дашлы, Сабаиль, палеогеографических, термобарических условий и скорости осадконакопления для оценки перспектив нефтегазоносности изучаемой зоны.

Методы. С помощью компьютерных программ проведена палеотектоническая и палеогеографическая реконструкция исследуемого региона и на основе накопленных палеогеографических данных построена тектоническая модель, отражающая палеотектонические особенности изучаемой территории, а также зоны осадконакопления.

Результаты. Были построены и проанализированы: схематическая карта, палеогеографическая гистограмма, графики скорости осадконакопления отдельных структур, палеотектонические профили, диаграмма изменения высоты складок в зависимости от времени. Исследования дали основание для нижеследующих выводов: изучение истории геологического развития локальных структур Аран-дениз, Дашлы и Сабаиль показало, что их развитие имеет конседиментационный характер; изучение палеогеографических условий и скорости осадконакопления по отдельным стратиграфическим единицам установило наличие благоприятных палеогеографических условий для накопления в потенциальных нефтематеринских породах разреза органического вещества выше кларкового числа; осложнение локальных структур грязевым вулканизмом дает возможность прийти к выводу о том, что на территории существовали достаточно благоприятные термобарические условия для генерации потенциальными нефтематеринскими пластами нефти и газа.

\section{Ключевые слова:}

Бассейн, структура, перспективность, литология, углеводород, порода, впадина, нарушение, свита, месторождение.

\section{Введение}

Осложненные грязевым вулканизмом структуры Аран-дениз-Дашлы и Сабаиль расположены в центральной части Бакинского архипелага в антиклинальной тектонической зоне ХамамдагАзизбеков. Как известно, Хамамдаг-Азизбековская тектоническая зона находится в Алятской гряде юго-восточного Гобустана и протягивается в море на более чем 50 км от Пирсаатского мыса $[1-5]$.

Антиклинальная зона объединяет в себе следующие структуры: Хамамдаг, Гарасу, Ульфат, Санги-Мугань, Аран-дениз, Дашлы, Сабаиль, Нахичевань и Азизбеков, которые осложнены разломами различных направлений: поперечными, продольными, радиальными, и, помимо этого, ситуация усугубляется наличием грязевых вулканов $[6,7]$. Надо отметить, что продольные разломы прослеживаются по всей зоне и имеют региональный характер. Разломы в молодых породах имеют относительно мелкие амплитуды. Сводовая часть этих структур, которые имеют в юго-восточном направлении ступенчато-блоковое тектоническое строение, сильно осложнена разломами (рис. 1).

По данным проведенных различных геологоисследовательских работ (картирование, структурно-разведочное и разведочное бурение) были изучены породы стратиграфических комплексов четвертичного периода и палеогена, которые участвуют в геологическом строении структур Арандениз, Дашлы и Сабаиль [3-5, 8, 9].

Поднятие Аран-дениз расположено к юго-востоку от поднятия Гарасу, и, горизонтально перемещаясь в юго-западном направлении, кулисообразно соединяется с ним. Структура Аран-дениз асимметрична: юго-западное крыло характеризуется более крутым, по сравнению с северо-восточным (угол залегания $10-30^{\circ}$ ), углом залегания в $20-35^{\circ}$. Короткая северо-западная периклиналь структуры залегает под углом приблизительно в $30-32^{\circ}$ и является более крутой, а юго-восточная периклиналь продолговатая и пологая $\left(18-20^{\circ}\right)$ (рис. $\left.1,2, a\right)$. 
СТРУКТУРНО-ТЕКТОНИЧЕСКАЯ СХЕМА БАКИНСКОГО АРХИПЕЛАГА

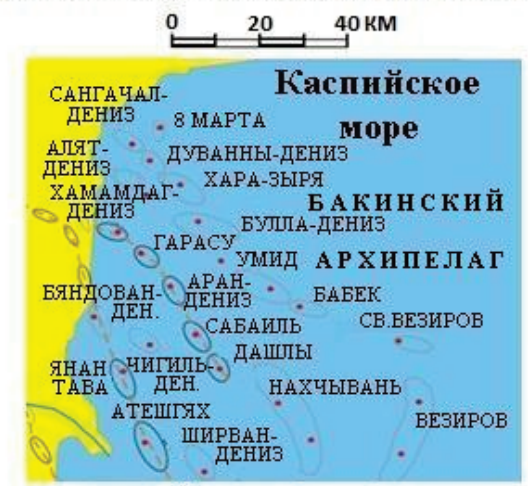

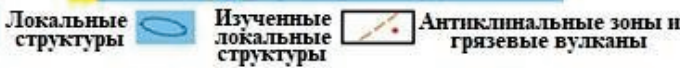

Puc. 1. Обзорная структурно-тектоническая схема Бакинского архипелага

Fig. 1. General structural-tectonic map of the Baku Archipelago
Как видно из структурно-тектонической карты, пласты, особенно верхнего отдела продуктивной толщи (ПТ), сильно осложнены региональными разломами и грязевым вулканизмом, что является основной причиной усугубления ситуации. Судя по пластам верхнего отдела ПТ, обнажающимся на дневной поверхности в сводовой части структуры, ее размеры составляют $3 \times 4,5$ км.

Брахиморфная структура Дашлы расположена между структурами Аран-дениз и Сабаиль. По подошве акчагильского яруса данное поднятие представляет собой слегка асимметричную складку северо-запад-юго-восточного простирания, характеризующуюся относительно круто $\left(20-25^{\circ}\right)$ залегающим юго-западным и пологим северо-восточным крыльями. Размеры складки $9 \times 4,5$ км по стратоизогипсе 1200 м свидетельствуют о том, что данное поднятие является короткой брахискладкой, близкой к изометричной [10-12].

Структура осложнена продольными и поперечными разломами. Гипсометрически более низкое,

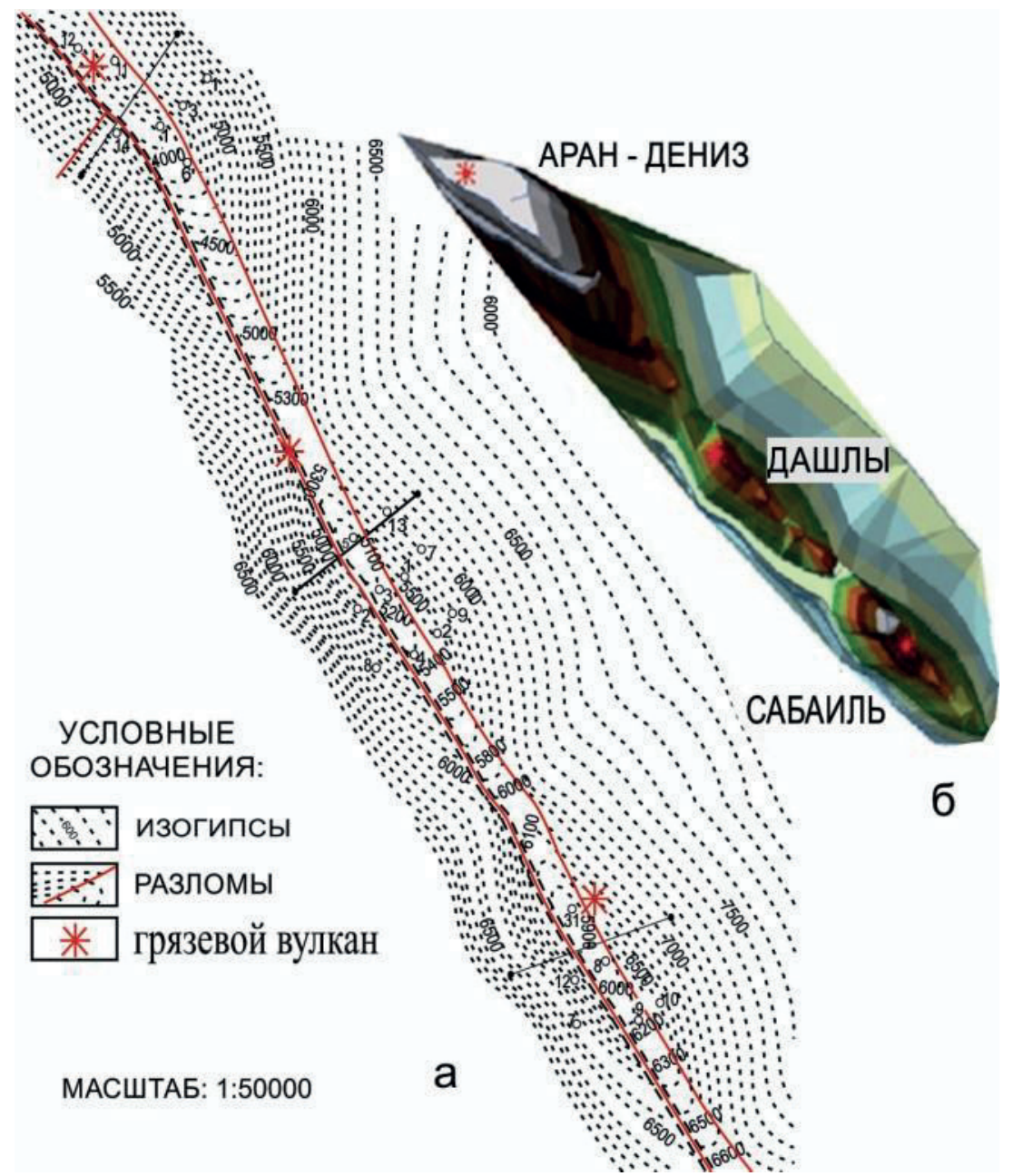

Рис. 2. Антиклинальная зона Аран-дениз-Дашль-Сабаиль. Структурная карта (а) и тектоническая модель (б) по кровле свиты «Фасиля» на основе палеогеографических данных

Fig. 2. Aran-deniz-Dashli-Sabail anticline zone. Structural map (a) and tectonic model (б) for the top of the «Fasila» suite based on paleogeographic data 
по отношению к соседним блокам, положение центрального тектонического блока продольного простирания, расположенного в сводовой части складки вдоль продольных разломов, создает систему тектонических блоков грабенового типа [13-15].

Надо отметить, что вся зона Аран-дениз-Дашлы расчленена продольными разломами на три блока: юго-западный (юго-западное крыло), центральный (приосевая часть) и северо-восточный (северо-восточное крыло) (рис. 2, $а$, б).

Изучаемая третья антиклинальная структура Сабаиль расположена юго-восточнее структуры Аран-дениз и относится к Хамамдаг-дениз-Сабаильской антиклинальной линии, которая простирается с севера-запада на юго-восток. Это поднятие является антиклинальной складкой северо-западюго-восточного простирания. Размеры этой относительно малоизученной структуры, по предполагаемой изолинии в 1300 м, а также изолинии в $1500 \mathrm{~m}$, приблизительно составляют $7 \times 3,5$ км. Предположительная амплитуда разломов колеблется между 350-400 м. Горизонты верхнего отдела ПТ (нижний плиоцен) залегают на глубине 1000 м, и вероятная мощность этих отложений составляет приблизительно 4600-4700 м (рис. 2, б) [16].

\section{Методы}

Для детального изучения и оценки нефтегазоносности ПТ в Сабаильской антиклинали в 1991 г. было начато бурение скважины с проектной глубиной 6200 м, седьмой горизонт был вскрыт на интервале 5857-5982 м. При опробовании объекта на глубине 5972-5975 м получена пластовая вода с растворенным в ней газом дебитом $700 \mathrm{~m}^{3} /$ сут. $[12,13]$.

По промыслово-геофизическим данным интервал глубин 5968-5977 м оценивался как нефтегазоносный, но, несмотря на это, опробование в данном объекте не проводилось.

Сравнение структур, которые находятся в одной и той же зоне, но на разных антиклинальных линиях, дает возможность использовать информацию о любой из них в качестве дополнительной.

Все изучаемые структуры осложнены разрывными нарушениями, имеющими свои особенности и отличительные параметры для каждого объекта, что дает возможность утверждать, что палеотектоническая обстановка и развитие, а также доминирующие силы горизонтального либо вертикального характера, участвующие в образовании складок, отличались друг от друга (рис. $2, a, \sigma, 3)[14,15]$.

Основной целью исследований является изучение палеогеографических условий и скорости осадконакопления, палеотектонических условий образования складок и разломов, а также оценка нефтегазоносности в эоцен-четвертичный геологический промежуток времени. Одновременно был изучен характер сформировавшихся нефтематеринских, коллекторских пород и покрышек, которые играют важную роль в образовании (при благоприятных термобарических условиях), накоплении и предотвращении разрушения уже сформировавшихся углеводородных залежей, оценены перспективы нефтегазоносности зоны. Комплексно изучая зону с точки зрения нефтегазоносности, особое внимание следует обратить на тектонические процессы, сопровождающиеся осадконакоплением и складкообразованием [15, 17-19].

Для решения поставленных задач был рассмотрен ряд характерных факторов их развития, а полученные данные по изучению палеогеографических условий дают возможность детальной оценки перспективности объектов в целом и отдельных горизонтов ПТ в частности $[18,20,21]$.

Для изучения палеогеографических условий осадконакопления нами-проанализирован средненормальный литолого-стратиграфический разрез, на основе которого была составлена палеогеографическая гистограмма (рис. 4). Данная гистограмма дала возможность установить палеогеографические условия осадконакопления от эоцена до современного времени (четвертичный век, плейстоцен).

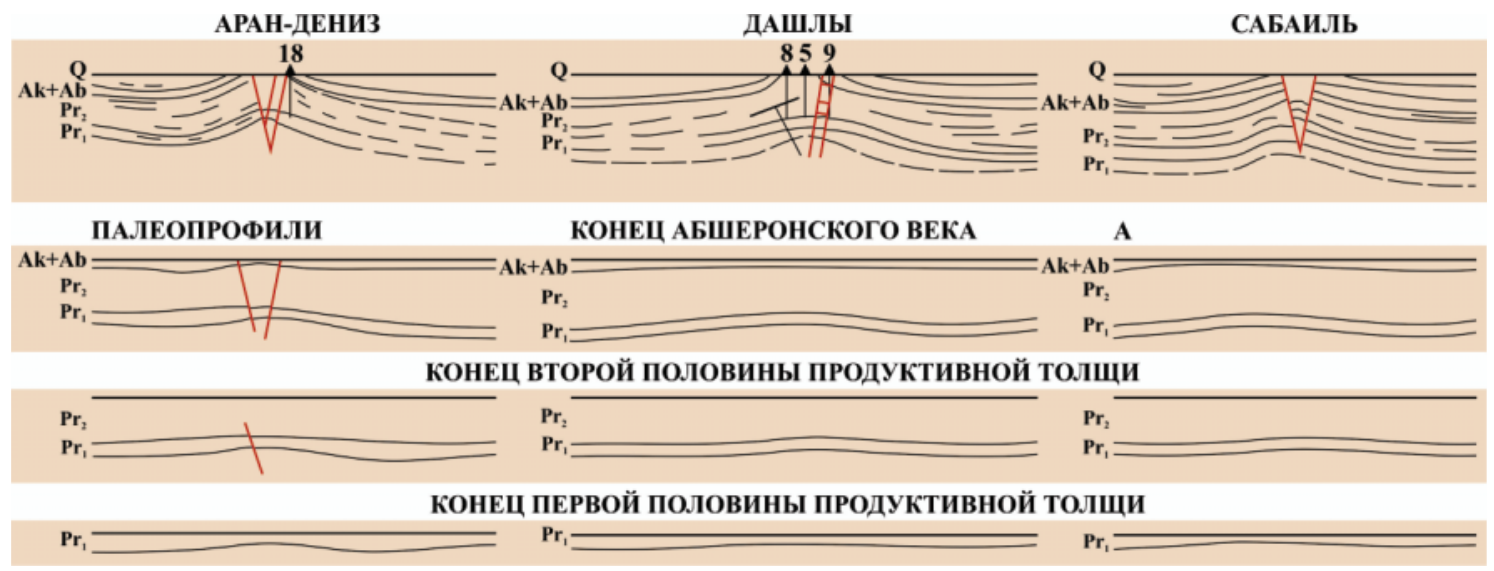

Рис. 3. Палеотектоническое развитие структур Аран-дениз, Дашлы и Сабаиль

Fig. 3. Paleotectonic evolution of the Aran-deniz, Dashli and Sabail structures 


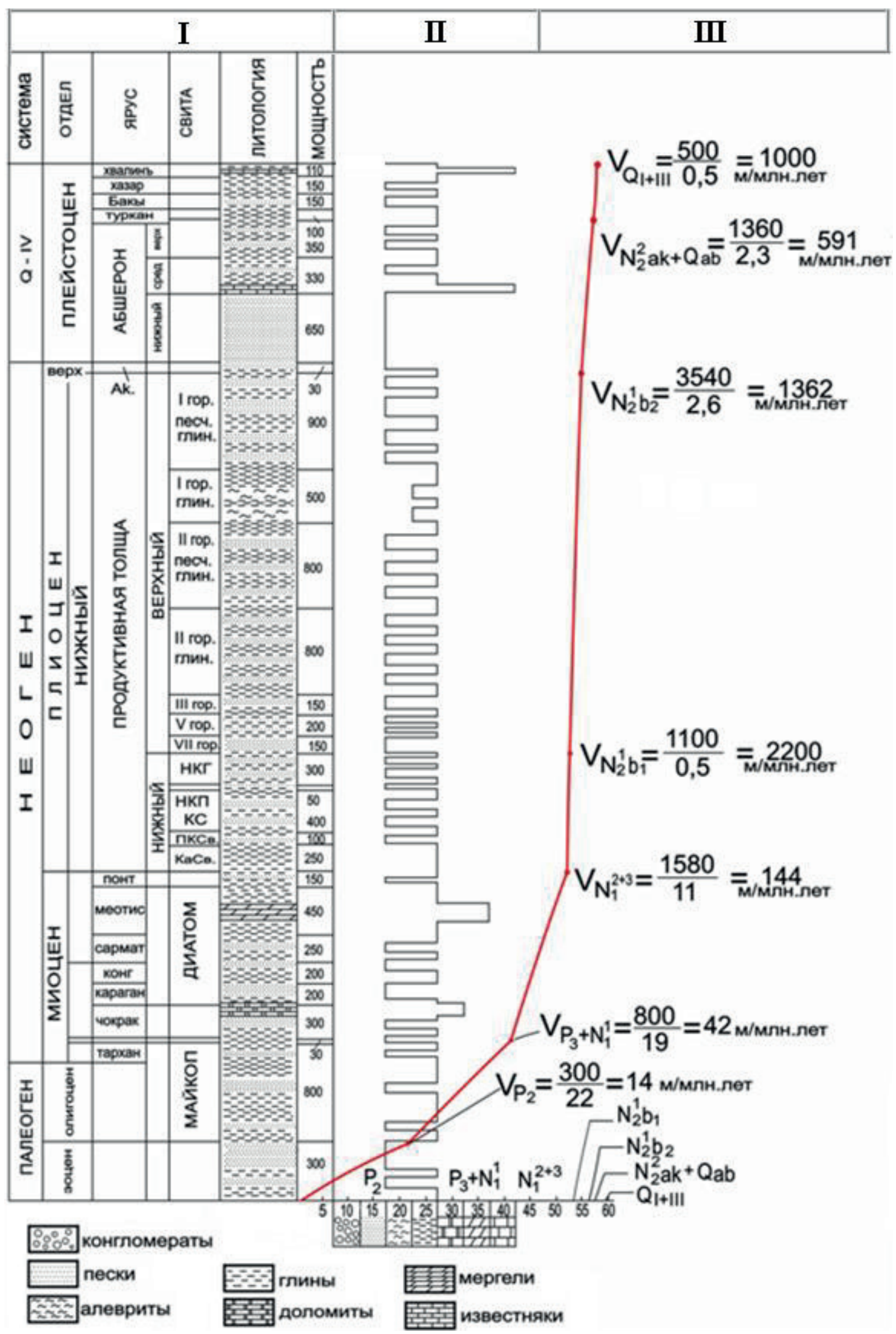

Рис.4. Палеогеографическая кривая и график интенсивности осадконпкопления. I - Средне-нормальный литолого-стратиграфический разрез площадей Аран-дениз, Дашлы, Сабаиль; II - Палеогеографическая кривая; III - график интенсивности осадконакопления

Fig. 4. Paleogeographic curve and the diagram of the deposition rate. I - General normal lithological stratigraphic section of the Aran-deniz, Dashli, Sabail area; II - Paleogeographic curve; III - Diagram of the deposition rate 


\section{Обсуждение}

На палеогеографической гистограмме видно, что глубина бассейна в эоцене была между средней и малой, и именно эти условия способствовали накоплению пелитовой и псаммитовой фаций. В майкопском веке бассейн в основном был средней глубины и была накоплена пелитовая фация большой мощности [17, 22-24].

В начале чокракского века по причине устойчивого воздымания дна бассейна была сформирована псаммитовая фация. В середине и к концу этого века под влиянием неустойчивых тектонических движений разного характера глубина бассейна колебалась между средней и большой величинами и в результате была сформирована сначала пелитовая, а во второй половине века карбонатная фации.

K началу диатомового века бассейн постепенно мелел. Поэтому в караганском полувеке в бассейне существовали положительные условия для формирования псаммитовой фации. Пелитовые отложения конкского возраста, перекрывающие караганские отложения, дают возможность прийти к выводу об относительном углублении бассейна.

В сарматском веке и в начале меотиса дно бассейна ритмично колебалось между мелкой и средней глубиной, разрез сформировался чередованием пелитовых и псаммитовых отложений. Начиная с конца сарматского века до середины понтского глубина бассейна была в основном средней. Но в середине меотиса бассейн начал углубляться и в результате была сформирована карбонатная фация, а следствием кратковременного относительного обмеления бассейна, которое произошло в конце понта, стало накопление пелитовой фации.

Надо отметить, что бассейн, сформировавшийся в калинском веке продуктивной толщи, подвергался воздействию отрицательных тектонических сил, и в результате в этой глубокой котловине с относительно небольшой площадью сформировалась в основном глинистая литофация. Начиная с калинского века вплоть до акчагыльского дно котловины подвергалось ритмическим тектоническим движениям отрицательного и положительного характера.

Подверженность тектоническим движениям приводила к изменению ее глубины, что соответствовало отдельным геологическим векам и полувекам, и, наряду с этим, площадь котловины увеличивалась с каждым новым ритмическим движением. Обобщая происходившее, надо отметить, что в этот промежуток времени была сформирована в основном пелитовая фация, которая чередовалась псаммитовыми пластами.

Начиная с акчагыльского века до конца нижнего абшерона в подвергавшемся воздымательным силам бассейне происходило обмеление, где сформировалась псаммитовая фация, а в начале среднего абшерона под воздействием отрицательных тектонических движений в бассейне произошло резкое углубление, в результате чего за относительно короткое геологическое время была сформирована карбонатная фация.

В тюрканском и бакинском полувеках дно бассейна устойчиво опускалось, сформировавшиеся здесь глинистые пласты характеризуются значительной мощностью. Начиная со второй половины бакинского до середины хазарского полувеков глубина бассейна ритмически колебалась между средней и малой. В хазарском полувеке бассейн обмелел настолько, что в результате сформировалась псефитовая фация относительно малой мощности. В конце хазарского и в начале хвалынского полувеков глубина бассейна характеризуется колебанием в пределах кратковременного мелководья и относительно дольшей средней глубины.

Обобщая характер изменчивости палеогеографической кривой, для изучаемого стратиграфического интервала укажем, что глубина бассейна всей зоны исследования колебалась в основном между средней и малой, при относительно доминирующей средней глубине, в результате чего в средне-стратиграфическом разрезе на площадях Аран-денизДашлы и Сабаиль доминирует пелитовая фация.

Как известно, в потенциальных нефтематеринских пластах между концентрацией органического вещества (OB) и скоростью осадконакопления существует прямая зависимость. Если скорость осадконакопления изменяется между 20-130 м/млн лет, то в таких бассейнах потенциал нефтематеринских пластов оценивается как высокий, и в этих осадках (породах) количество ОВ достигает, приблизительно, двух процентов. Однако при превышении скорости 1600 м/млн лет концентрация OB в осадках начинает уменьшаться $[18,20]$.

Анализ палеогеографической гистограммы и скорости осадконакопления показывает, что в эоценовую эпоху она не была высокой, т. е. осадконакопление происходило умеренными темпами, составляя 14 м/млн лет (рис. 4). Естественно, при таком темпе осадконакопления количество ОВ в осадках не может быть значительным.

При формировании пород майкопской серии скорость осадконакопления составляла более $42 \mathrm{~m} /$ млн лет. Учитывая то, что в это геологическое время в ЮКБ при накоплении осадков дно бассейна погрузилось приблизительно до 400 м и осадки накапливались в бассейне, характеризующемся стоячими условиями, то именно этот период времени и палеогеографические условия можно принять в качестве самых благоприятных для сохранения ОВ в потенциальных нефтематеринских пластах.

Отметим, что в среднем и верхнем миоцене скорость осадконакопления составляла $144 \mathrm{~m} / \mathrm{млн}$ лет, что является показателем наличия большого количества ОВ, а глинистость диатомовой свиты, которая составляет подавляющую часть всего миоценового периода, указывает на наличие потенциальных нефтематеринских пластов и высокую сохранность ОВ. 
В нижнем полувеке ПТ скорость осадконакопления в бассейне составляла 2200 м/млн лет. Этот показатель дает возможность охарактеризовать эту достаточно высокую скорость накопления осадков как неблагоприятную, т. к. при данных условиях количество (концентрация) накопленных и сохранившихся органических веществ в пластах заметно уступало количеству ОВ в породах, сформировавшихся в более благоприятных условиях осадконакопления в течение верхней части нижнего отдела ПТ. При такой большой скорости осадконакопления ОВ накапливалось в недостаточном количестве, чем можно объяснить низкий потенциал генерации УВ в сформировавшихся нефтегазопорождающих образованиях. В верхнем полувеке ПТ скорость осадконакопления составляла 1362 м/млн лет. При такой скорости потенциал нефтематеринских пластов может достичь $10 \%$, а иногда и более. Как видно из вышеизложенного, в породах ПТ количество органического вещества на порядок больше кларкового числа и эти условия позволяют нефтематеринским породам порождать промышленные запасы нефти. Проведённые исследования показывают, что особенно верхний полуярус ПТ пока не полной своей мощностью вошел в главную зону нефтегенерации. По этой причине коллекторы ПТ насыщаются углеводородами в основном за счёт нижележащих (например, майкоп, диатом) нефтегенерирующих пластов, которые в данное геологическое время генерируют углеводороды.

В позднем плиоценовом полувеке, т. е. в акчагыльской и абшеронской эпохах, скорость осадконакопления составляла 591 м/млн лет. Как видно из литолого-стратиграфического разреза, осадки, накопленные в этот век, однозначно сложены псаммитовой фацией. Это дает возможность предположить, что, несмотря на высокую скорость осадконакопления, потенциал нефтегазогенерации практически нулевой ввиду отсутствия в разрезе нефтематеринских пластов.

Наконец, изучая породы четвертичных осадков, содержащих нефтематеринские пласты, было установлено, что в данный геологический промежуток скорость осадконакопления составляла приблизительно 1000 м/млн лет. Исследованиями выявлено, что в этих потенциальных нефтематеринских породах был образован углеводородный газ. Однако по причине того, что эти породы в данный момент не были вовлечены в главную зону нефтегенерации, об их потенциале нефтепорождения говорить пока рано.

Из вышеизложенного можно прийти к выводу о том, что в рассматриваемом стратиграфическом интервале к основным нефтегенерирующим комплексам можно отнести майкопские, средне-, верхнемиоценовые породы и ПТ.

Как известно, одним из эффективных методов прогнозирования нефтеносности недр земли является изучение истории развития локальных поднятий $[7,24]$. В связи с этим нами проанализирован ряд полеопрофилей по нижней и верхней ПТ и к концу абшеронского века с использованием данных двух поперечных сейсмогеологических профилей, проходящих по структурам Аран-дениз, Дашлы, Сабаиль. Кроме этого, были построены графики интенсивности развития структур (таблица, рис. 5).

По палеопрофилю к концу нижней продуктивной толщи структуры Аран-дениз видно, что складка была выражена уже в начале ПТ, а это показывает, что в изучаемой зоне поднятие начало свое развитие не позднее начала плиоцена. По этой причине мощность осадков (пластов) нижней ПТ в сводовой части структуры значительно меньше по сравнению с крыльевыми зонами. Надо отметить, что к концу нижней продуктивной толщи высота структуры Аран-дениз достигала 500 м.

Развитие складки продолжалось с меньшей интенсивностью и в верхней ПТ, что можно проследить в разнице мощностей в сводовой и крыльевой частях складок. Кроме этого, в верхнем полувеке ПТ сводовая часть структуры была осложнена разрывными нарушениями сбросового характера. Скорость развития структуры, по сравнению с началом века продуктивной толщи, постепенно уменьшалась и в этом полувеке её высота достигала $400 \mathrm{~m}$.

таблица. Изменение высоты складок согласно их развитию в соответствующих стратиграфических единицах

Table. $\quad$ Variation of the fold amplitude according to their evolution within corresponding stratigraphic units

\begin{tabular}{|c|c|c|c|c|c|c|c|c|}
\hline \multirow[b]{2}{*}{$\begin{array}{l}\text { Структуры } \\
\text { Structures }\end{array}$} & \multicolumn{2}{|c|}{$\begin{array}{c}\text { Нижняя ПТ } \\
\text { Lower PS }\end{array}$} & \multicolumn{2}{|c|}{\begin{tabular}{|c|} 
Верхняя ПТ \\
Top PS
\end{tabular}} & \multicolumn{2}{|c|}{$\begin{array}{c}\text { Акчагиль } \\
\text { Akchagil }\end{array}$} & \multicolumn{2}{|c|}{$\begin{array}{l}\text { Четвертичный век } \\
\text { Quarternary century }\end{array}$} \\
\hline & $\begin{array}{c}\mathrm{H}, \mathrm{M} \\
(\mathrm{m})\end{array}$ & 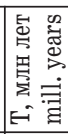 & $\begin{array}{c}\mathrm{H}, \mathrm{M} \\
(\mathrm{m})\end{array}$ & 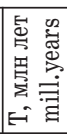 & $\begin{array}{c}\mathrm{H}, \mathrm{M} \\
(\mathrm{m})\end{array}$ & 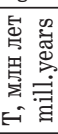 & $\mathrm{H}, \mathrm{M}(\mathrm{m})$ & 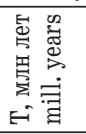 \\
\hline $\begin{array}{l}\text { Аран-дениз } \\
\text { Aran-deniz }\end{array}$ & 500 & \multirow{3}{*}{0,5} & 950 & \multirow{3}{*}{2,6} & 1300 & \multirow{3}{*}{1,7} & 3200 & \multirow{3}{*}{0,4} \\
\hline $\begin{array}{c}\text { Дашлы } \\
\text { Dashli }\end{array}$ & 400 & & 650 & & 1200 & & 2600 & \\
\hline $\begin{array}{c}\text { Сабаиль } \\
\text { Sabail }\end{array}$ & 250 & & 500 & & 1150 & & 2200 & \\
\hline
\end{tabular}

Палеопрофили, которые проясняют ситуацию к концу абшеронского века, показывают, что развитие структуры продолжалось и характеризовалось разностью в интенсивности осадконакопления в крыльях, т. е. осадконакопление на юго-западном крыле проходило относительно более интенсивно, чем на северо-восточном. Интенсивность развития структуры постепенно уменьшалась и это продолжалось как в позднем плиоцене, так и в начале четвертичного века. В результате затухания в развитии структуры, что привело к ее погребению, высота структуры Аран-дениз составила лишь 300 м. Различная интенсивность формирования крыльев могла обусловить наличие взбросового нарушения в сводовой части этой структуры.

Надо отметить, что в четвертичном веке результатом увеличения темпа роста структуры стало об- 
разование дополнительных разрывных нарушений разного масштаба и направления в ее присводовой части. В результате интенсивных положительных тектонических движений высота поднятия Аран-дениз в четвертичном веке достигла 2000 м. К тому же в результате высокой скорости воздымания структуры, превосходившей скорость осадконакопления, в сводовой части структуры не присутствуют породы четвертичного века, а около 400 м осадков верхнего плиоцена были размыты.

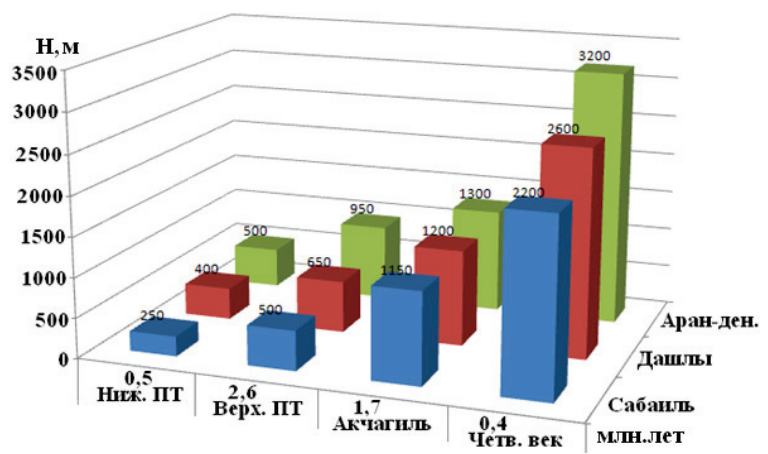

Pис.5. Диаграмла изменения высоты складок в зависимости от времени

Fig. 5. Chart of the fold amplitude variation as a function of time

Развитие поднятий Дашлы и Сабаиль началось не позже конца миоценового века. Их высота к концу нижней продуктивной толщи достигала 400 м. В верхней продуктивной толще формирование этих структур относительно замедлилось и в результате, к концу этого века, их высота составила, соответственно, 600 и 500 м. Несмотря на то, что в процессе роста этих поднятий скорость структуры Дашлы превосходила скорость структуры Сабаиль, в позднем плиоцене её высота достигала всего лишь 1100 м.

Исследование показывает, что в четвертичном веке скорость вздымания этих двух структур Дашлы и Сабаиль, резко повысилась.

По сейсмогеологическим профилям в синклинальных впадинах, смежных со структурой Дашлы, мощность четвертичных отложений составляет 2600 м. По профильной линии высота складки Дашлы в настоящее время составляет 2400, а структуры Сабаиль - 2200 м. Однако надо отметить, что рассматриваемая линия профиля не проходит по своду структуры, и поэтому нет возможности судить об истинной ее высоте. Все вышеуказанное наблюдается как в юго-западном, так и в северо-восточном направлениях.

Кроме этого, исследования показывают, что все структуры начали свое развитие уже в конце позднего миоцена и развитие происходило параллельно с осадконакоплением. Такое своеобразное развитие структур оказало свое влияние на специфику локального распределения привнесенного в бассейн осадочного материала. Эти условия стали причинами того, что в синклинальных впадинах вокруг складок были сформированы в основном гли- нистые образования, тогда как в сводовых и относительно возвышенных частях структур были накоплены пески и песчаники. Кроме этого, в сводовых и присводовых частях антиклиналей скорость осадконакопления пропорционально уменьшалась в соответствии с интенсивностью их развития.

Наряду с этим можно предположить, что средне- и верхнемиоценовые отложения мощностью 2,5-3,0 км создали необходимое геостатическое давление над майкопскими глинами, начавшими адвекцию для запуска механизма поперечного изгиба при нарушении гидростатического равновесия в Южно-Каспийском бассейне (ЮКБ) в пределах Бакинского архипелага [12].

\section{Результаты}

В результате проведенных исследований выяснилось, что нарушение гидростатического равновесия в ЮКБ могло произойти как за счет вертикальных движений отдельных блоков кристаллического фундамента вдоль глубинных разломов, так и за счет напряжений сжатия, возникших в осадочном чехле ЮКБ.

Главной причиной возникновения напряжений сжатия в осадочном чехле ЮКБ являются геодинамические процессы, связанные с зонами коллизии и остаточной субдукции $[12,18]$.

Анализ палеопрофилей показывает, что начало развития разломных нарушений тектонического характера совпадает с периодом самого интенсивного развития складок. В итоге большинство нарушений, осложняющих локальные структуры, либо начинали свое развитие в четвертичном периоде, либо же были реактивизированы. Этот процесс может стать причиной дегерметизации локальных поднятий. Если эти разрывные нарушения достигают дна бассейна, то они могут сыграть большую роль в разрушении и, возможно, в зависимости от обстановки, в повторном формировании залежей.

Особенности развития изучаемых нами локальных структур дают возможность высоко оценить перспективность их нефтегазоносности. Надо отметить, что складки, подвергшиеся глубокой эрозии и сильно осложненные тектоническими разломами, интересны с точки зрения нефтеносности, а слабо осложненные, или почти не подвергшиеся эрозии могут считаться более благоприятными для формирования в них газовых и газоконденсатных залежей.

\section{Заключение}

1. Изучение истории геологического развития локальных структур Аран-дениз, Дашлы и Сабаиль показало, что их развитие имеет конседиментационный характер.

2. Исследование палеогеографических условий скорости осадконакопления по отдельным стратиграфическим единицам указало на наличие благоприятных палеогеографических условий для накопления в потенциальных нефтема- 
теринских породах разреза органического вещества выше кларкового числа.

3. Осложнение локальных структур грязевым вулканизмом дает возможность прийти к выво-

\section{СПИСОК ЛИТЕРАТУРЫ}

1. Рахманов И.П. Грязевые вулканы и их значение в прогнозировании нефтегазоносности недр. - М.: Недра, 1987. - 271 с.

2. Бабаев Д.Х., Гаджиев А.Н. Глубинное строение и перспективы нефтегазоносности бассейна Каспийского моря. - Баку, NAFTA Press, 2006. - 305 c.

3. Абдулгасанова Л.Д., Мамедова С.Р., Аллахвердиев Е.Г. Отчет по площадям Сангачал-дениз-Дуванны-дениз-Харе-Зыря в Бакинском архипелаге по двухмерным (2D) сейсморазведочным работам. - Баку: Кешфийятгеофизика ОП, 2018. - 147 с.

4. Gahramanov G.N. Formation of the oil and gas reservoirs in deep water areas of the South Caspian Depression // Earth Sciences Research Journal. - 2017. - V. 21. - № 4. - P. 169-174. URL: https://revistas.unal.edu.co/index.php/esrj/article/view/64008 (дата обращения 28.01.2019).

5. Isgandarov M.M. Some Results of Modeling Electrical Resistivity (on the Example of Deposits of the South-Absheron Aquatic Zone and the Northern Part of the Baku Archipelago) // SOCAR PR0CEEDINGS. - 2017. - Iss. 2. - P. 4-12. URL: http://proceedings.socar.az/az/journal/49 (дата обращения 28.01.2019).

6. Алиев Ад.А. Грязевой вулканизм Южно-Каспийского нефтегазоносного бассейна // Геология и полезные ископаемые Мирового океана. - 2006. - № 3. - С. 12-21.

7. Mukhtarova K.Z., Nasibova G.J., Ahmadov M.G. The role of SouthEastern Gobustan and Absheron depression clays with rheologically active properties in formation of structures and mud volcanism // American Collocational Researcher Association, Washington Educational Researcher. - 2016, December. - № 9. - P. 673-678.

8. Багир-заде Ф.М., Керимов К.М., Салаев С.Г. Глубинное строение и нефтегазоносность Южно-Каспийской мегавпадины. Баку, Аз.Гос.Издат., 1987. -302 с.

9. Каграманов К.Н., Мухтарова Х.З. Факторы, влияющие на формирование резервуаров крупных размеров и условия сохранения залежей нефти и газа на больших глубинах Южно-Каспийской впадины // Геология, геофизика и разработка нефтяных и газовых месторождений. - 2016. - № 3. - С. 25-33.

10. Буниат-заде 3.А., Салаев Н.С. Геолого-тектонические условия формирования приразрывных зон нефтегазонакопления в Южном Каспии // Геолог Азербайджана. - 2000. - № 4. C. $64-72$.

11. Высоцкий И.В., Высоцкий В.И. Формирование нефтяных, газовых и газоконденсатных месторождений. - М.: Недра, 1986. -228 c.

12. Нариманов Н.Р., Кулиев К.Г. Изучение истории развития локальных поднятий Бакинского архипелага аналитическим ме- ду о том, что на территории существовали достаточно благоприятные термобарические условия для порождения потенциальными нефтематеринскими пластами нефти и газа.

тодом // Известия Национальной Академии Наук Азербайджана. Науки о Земле. - 2003. - № 1. - С. 18-24.

13. Керимов В.Ю., Мухтарова Х.З., Мустаев Р.Н. Дизъюнктивные нарушения и их роль в формировании и разрушении залежей нефти и газа в Южном Каспии / / Нефть, газ и бизнес. - 2011. № 6. - C. $18-26$.

14. Нариманов Н.Р. Геодинамические аспекты формирования осадочного чехла Южно-Каспийской впадины // Геология нефти и газа. - 2003. - № 6. - С. 7-11.

15. Cenozoic stage of development of local structures of the Lower Kura Depression and Baku Archipelago related to their oil and gas prospects / N.R. Narimanov, N.A. Babayev, G. Gahramanov, Z. Javad-Zadeh // Geological Journal. - 2018. - V. 53. - № 1. P. 1-12. URL: https://onlinelibrary.wiley.com/doi/abs/ $10.1002 /$ gj.3304 (дата обращения 28.01.2019).

16. Нариманов Н.Р. Влияние геодинамических процессов на нефтегазообразование в Южно-Каспийской впадине // Азербайджанское нефтяное хозяйство. - 2008. - № 8. - С. 13-18.

17. Mamedov P.Z., Babayev D.Kh. South Caspian Megatrough Seismostratigraphy // AAPG International Conference. - Nice, France, 1995. - P. 527-539.

18. Соколов Б.А. Эволюционно-динамические критерии оценки нефтегазоности недр. - М.: Недра, 1985. - 247 с.

19. Abdullayev E., Leroy S.A.G. Provenance of clay minerals in the sediments from the Pliocene Productive Series, western South Caspian Basin // Marine and petroleum geology. - 2016. V. 73. - P. 517-527.

20. Вассоевич Н.Б., Баженова 0.К., Бурлин Ю.К. Нефтематеринский потенциал осадочных образований // Итоги науки и техники. Сер. Месторождения горючих полезных ископаемых. 1982. - № 11. - C. 37-43.

21. Selley R.C. Elements of petroleum geology. $2^{\text {nd }}$ ed. - London, United Kingdom: Academic Press, 1998. - 479 p.

22. Гамкрелидзе И.П. Мобилизм и проблемы тектоники Кавказа // Проблемы геодинамики Кавказа. - М.: Наука, 1982. - С. 4-8.

23. Geosciences of Azerbaijan / A.A. Alizadeh, I.S. Guliyev, F.A. Kadirov, L.V. Epelbaum // Geology. - 2016. - V. I. - 340 p.

24. Geosciences of Azerbaijan / A.A. Alizadeh, I.S. Guliyev, F.A. Kadirov, L.V. Epelbaum // Economic Geology and Applied Geophysics. - 2017. - V. I. URL: https://www.sciencedirect.com/science/article/pii/S0264817216300599?via\%3Dihub (дата обращения 28.01.2019).

\section{Информация об авторах}

Нариманов Н.P., кандидат геолого-минералогических наук, доцент кафедры геологии нефти и газа Азербайджанского Государственного Университета Нефти и Промышленности.

Мухтарова Х.З., кандидат геолого-минералогических наук, доцент кафедры геологии нефти и газа Азербайджанского Государственного Университета Нефти и Промышленности.

Насибова Г.Д., кандидат геолого-минералогических наук, доцент кафедры геологии нефти и газа Азербайджанского Государственного Университета Нефти и Промышленности. 


\section{GEOLOGICAL EVOLUTION AND OIL AND GAS CONTENT OF LOCAL UPLIFTS OF THE BAKU ARCHIPELAGO OF THE SOUTH CASPIAN BASIN}

Nariman R. Narimanov', nariman.narimanov40@asoiu.edu.az

Khuraman Z. Mukhtarova', mukhtarova.khuraman@mail.ru

Gulter J. Nasibova', gultar_nasibova_1@yahoo.com

'Azerbaijan State Oil and Industry University, 20, Azadliq avenue, Baku, AZE1010, Azerbaijan.

The research relevance is backed by the need to expand the resource potential of the western flank of the South Caspian basin and increase production in some oilfields of the Baku Archipelago.

The aim of the research is to determine structural evolution features, paleogeographic, pressure and temperature environment and the deposition rate in order to assess oil and gas opportunities of the area under investigation.

Methods. Paleotectonic and paleogeographic reconstruction of the area under investigation were conducted using computer software and a tectonic model of the deposition zone was constructed based on paleogeographic data.

Results. The authors have constructed the schematic map, paleogeographic histogram, deposition rate diagrams for individual structures, paleotectonic profiles, a chart of the fold amplitude variation as a function of time and analyzed using computer technologies. The studies allow making the following conclusions: study of the history of geologic evolution of the local structures Aran-deniz-Dashli and Sabail showed that their development is syndepositional by nature; study of paleogeographic environments and deposition rates of individual stratigraphic units identified the presence of favorable paleogeographic conditions for accumulation of organic matter in source rocks of the section above the Clarke number; complication of local structures by mud volcanoes as well as analysis of geothermal data throughout the section allow making the conclusion on existence of quite favorable pressure and temperature environment for oil and gas generation in potential source rocks.

\section{Key words:}

Basin, structure, opportunities, lithology, hydrocarbon, rock, depression, fault, suite, oilfield.

\section{REFERENCES}

1. Rakhmanov I.P. Gryazevye vulkany i ikh znachenie v prognozirovanii neftegazonosnosti nedr [Mud volcanoes and their importance in predicting oil and gas content of the subsoil]. Moscow, Nedra Publ., 1987. $271 \mathrm{p}$.

2. Babaev D.K., Gadzhiev A.N. Glubinnoe stroenie i perspektivy neftegazonosnosti basseyna Kaspiyskogo morya [Depth structure and oil-and-gas bearing prospects of the Caspian Sea basin]. Baku, NAFTA Press, 2006. 305 p.

3. Abdulgasanov L.D., Mamedova S.R., Allakhverdiev E.G. Otchet po ploshchadyam Sangachal-deniz-Duvanni-deniz-Khare-Zirya $v$ Bakinskom arkhipelage po dvukhmernym (2D) seysmorazve dochnym rabotam [Report on Sangachal-deniz-Duvanny-denizKhare-Zyra in Baku archipelago on two-dimensional (2D) seismic survey]. Baku, Keshfiyatgeofizika OP, 2018. 147 p.

4. Gahramanov G.N. Formation of the oil and gas reservoirs in deep water areas of the South Caspian Depression. Earth Sciences Research Journal, 2017, vol. 21, no. 4, pp. 169-174. Available at: https://revistas.unal.edu.co/index.php/esrj/article/view/64008 (accessed 28 January 2019).

5. Isgandarov M.M. Some Results of Modeling Electrical Resistivity (on the Example of Deposits of the South-Absheron Aquatorium Zone and the Northern Part of the Baku Archipelago). SOCAR PROCEEDINGS, 2017, Iss. 2, pp. 4-12. Available at: http://proceedings.socar.az/az/journal/49 (accessed 28 January 2019).

6. Aliyev Ad. Mud volcanism of the South Caspian oil-and-gas bearing basin. Geology and mineral resources of World Ocean, 2006, no. 3, pp. 12-21. In Rus.
7. Mukhtarova K.Z., Nasibova G.J., Ahmadov M.G. The role of South-Eastern Gobustan and Absheron depression clays with rheologically active properties in formation of structures and mud volcanism. American Collocational Researcher Association, Washington Educational Researcher, 2016, December, no. 9, pp. 673-678.

8. Bagir-zade F.M., Kerimov K.M., Salaev S.G. Glubinnoe stroenie $i$ neftegazonosnost Yuzhno-Kaspiyskoy megavpadiny [Deep structure and oil-and-gas bearing of the South Caspian megadepression]. Baku, Az. Gos. Izdat. Publ., 1987. 302 p.

9. Kaqramanov K.N., Mukhtarova K.Z. Factors affecting the formation of reservoirs of large dimensions and the conditions for preservation of oil and gas deposits at great depths of the South Caspian depression. Geology, geophysics and development of oil and gas fields, 2016, no. 3, pp. 25-33. In Rus

10. Buniat-zade Z.A., Salayev N.S. Geological and tectonic conditions of formation of oil and gas accumulation at the fault zone in the South Caspian. Azerbaijan Geologist, 2000, no. 4, pp. 64-72. In Rus.

11. Vysotskiy I.V., Vysotskiy V.I. Formirovanie neftyanykh, gazovykh $i$ gazokondensatnykh mestorozhdeniy [Formation of oil, gas and gas condensate fields]. Moscow, Nedra Publ., 1986. 228 p.

12. Narimanov N.R., Kuliyev K.Q. Studying the history of development of local uplifts of the Baku archipelago by an analytical method. Azerbaijan National Academy of Sciences Transactions. Earth Sciences, 2003, no. 1, pp. 18-24. In Rus.

13. Kerimov V.Y., Mukhtarova K.Z., Mustayev R.N. Disjunctive dislocations and their effect in formation and distruction of oil and 
gas accumulations in the South Caspian. Oil, Gas and Business, 2011, no. 6, pp. 18-26. In Rus.

14. Narimanov N.R. Geodynamic aspects of the formation of the sedimentary cover of the South Caspian depression. Oil and gas geology, 2003, no. 6, pp. 7-11. In Rus.

15. Narimanov N.R., Babayev N.A., Gahramanov G.N., Javad-Zadeh Z. Cenozoic stage of development of local structures of the Lower Kura Depression and Baku Archipelago related to their oil and gas prospectivity. Geological Journal, 2018, vol. 53, no. 1, pp. 1-12. Availabla at: https://onlinelibrary.wiley.com/doi/ abs/10.1002/gj.3304 (accessed 28 January 2019). 2018,

16. Narimanov N.R. The influence of geodynamic processes on oil and gas formation in the South Caspian depression. Azerbaijan Oil Industry, 2008, no. 8, pp. 13-18. In Rus.

17. Mamedov P.Z., Babaev D.Kh. South Caspian Megatrough Seismostratigraphy. AAPG International Conference. Nice, France, 1995. pp. 527-539.

18. Sokolov B.A. Evolyutsionno-dinamicheskie kriterii otsenki neftegazonosnosti nedr [Evolutionary-dynamic criteria for assessing the oil and gas bearing of the subsoil]. Moskva, Nedra Publ., $1985.247 \mathrm{p}$.
19. Abdullayev E., Leroy S.A.G. Provenance of clay minerals in the sediments from the Pliocene Productive Series, western South Caspian Basin. Marine and petroleum geology, 2016, vol. 73, pp. 517-527.

20. Vassoyevich N.B., Bazhenova 0.K., Burlin Y.K. Oil potential of sedimentary formations. Outcomes of Science and Technology, 1982, no. 11, pp. 37-43. In Rus.

21. Selley R.C. Elements of petroleum geology. $2^{\text {nd }}$ ed. London, United Kingdom, Academicpress, $1998.479 \mathrm{p}$.

22. Gamkrelidze I.P. Mobilizm i problemy tektoniki Kavkaza [Mobilism and the problems of the tectonics of the Caucasus]. Problemi geodinamiki Kavkaza [Issues of Caucasus Geodynamics]. Moscow, Nauka Publ., 1982. pp. 4-8.

23. Alizadeh A.A., Guliev I.S., Kadirov F.A., Epelbaum L.V. Geosciences of Azerbaijan. Geology, 2016, vol. I, 340 p.

24. Alizadeh A.A., Guliyev I.S., Kadirov F.A., Epelbaum L.V. Geosciences of Azerbaijan. Economic Geology and Applied Geophysics, 2017, vol. I, 340 p. Available at: https://www.sciencedirect.com/science/article/pii/S0264817216300599?via\%3Dihub (accessed 28 January 2019).

Received: 1 February 2019.

\section{Information about the authors}

Nariman R. Narimanov, Cand. Sc., associate professor, Azerbaijan State Oil and Industry University.

Khuraman Z. Mukhtarova, Cand. Sc., associate professor, Azerbaijan State Oil and Industry University.

Gulter J. Nasibova, Cand. Sc., associate professor, Azerbaijan State Oil and Industry University. 